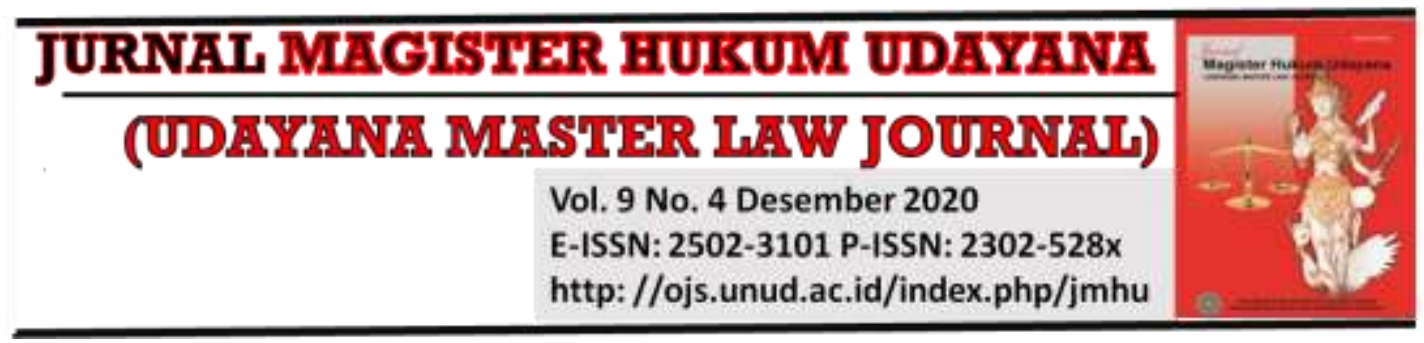

\title{
Perlindungan Hukum Bagi Pemilik Tanah dalam Akta Jual Beli Tanah PPAT yang Batal Demi Hukum oleh Putusan Pengadilan
}

\author{
Muhammad Rizky ${ }^{1}$, Muzakkir Abubakar ${ }^{2}$, Teuku Muttaqin Mansur ${ }^{3}$ \\ ${ }^{1}$ Program Studi Magister Kenotariatan, Universitas Syiah Kuala, \\ E-mail: muhammad.rizky39@gmail.com \\ ${ }^{2}$ Fakultas Hukum, Universitas Syiah Kuala, E-mail: muzakkir@unsyiah.ac.id \\ ${ }^{3}$ Fakultas Hukum, Universitas Syiah Kuala, E-mail: tmuttaqien@unsyiah.ac.id
}

\begin{abstract}
Info Artikel
Masuk: 2 September 2020

Diterima: 28 Desember 2020

Terbit: 31 Desember 2020

Keywords:

Legal protection; Canceled by

the Law; Land Deed Making

Official
\end{abstract}

Kata kunci:

Akta Jual Beli Tanah; Batal

Demi Hukum; Pejabat Pembuat

Akta Tanah

Corresponding Author:

Muhammad Rizky, E-mail:

muhammad.rizky39@gmail.com

DOI:

10.24843/JMHU.2020.v09.i04. p15

\begin{abstract}
PPAT's authority in making a land sale and purchase deeds must take into account the provisions of Article 22 PP No. 37 of 1998 that: the PPAT deed must be read/enforced to the party in the presence of at least two witnesses before being signed immediately by the parties, witnesses and PPAT. In practice, in the decision of the Ungaran District Court No.80 / Pdt.G / 2015 / PN.Unr, the PPAT land sale and purchase certificate was never signed by the landowner and in the decision of the Tanjung Karang District Court No.35 / Pdt.G / 2015 / PN. Tjk, the legal owner of the land certificate for joint assets does not have the wife's consent letter that is entitled to the land sale and purchase certificate. On this basis, the related parties submitted a cancellation of the issuance of the land sale and purchase certificate, so that the agreement was null and void. The purpose of this research is to analyze the responsibilities of PPAT, how to protect the law for landowners as a result of the issuance of the PPAT land sale and purchase certificate. This type of research is normative juridical with an inviting approach and a case approach. The source of legal material used is secondary data which is analyzed qualitatively and comes from deductive. The research results reveal that whether the legal protection for landowners in the PPAT land sale and purchase deed is null and void by a court decision has provided protection and legal certainty.
\end{abstract}

Abstrak

Kewenangan PPAT dalam membuat akta jual beli tanah harus memperhatikan ketentuan Pasal 22 PP No. 37 Tahun 1998 bahwa : akta PPAT harus dibacakan/dijelaskan kepada para pihak dengan dihadiri oleh sekurang-kurangnya dua orang saksi sebelum ditandatangani seketika itu juga oleh para pihak, saksisaksi dan PPAT. Prakteknya dalam putusan Pengadilan Negeri Ungaran No.80/Pdt.G/2015/PN.Unr, akta jual beli tanah PPAT tidak pernah ditandatangani oleh pemilik tanah dan dalam putusan Pengadilan Negeri Tanjung Karang No.35/Pdt.G/2015/PN.Tjk, pemilik sah sertifikat tanah atas harta bersama tidak terdapat surat persetujuan istri yang berhak dalam akta jual beli tanah. Atas dasar tersebut, para pihak terkait mengajukan pembatalan atas lahirnya akta jual beli tanah, agar perjanjian tersebut batal demi hukum. Tujuan penelitian ini 


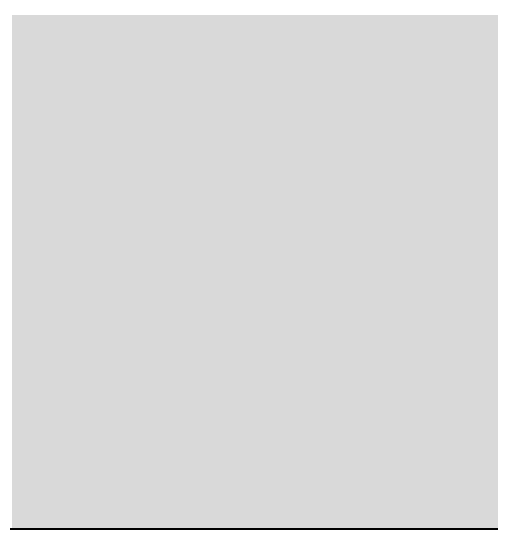

adalah untuk menganalisis bagaimana tanggung jawab PPAT, bagaimana perlindungan hukum bagi pemilik tanah akibat dari lahirnya akta jual beli tanah PPAT. Jenis penelitian yang digunakan bersifat yuridis normatif dengan pendekatan perundang-undangan dan pendekatan kasus. Sumber bahan hukum yang digunakan adalah data sekunder yang dianalisis secara kualitatif dan ditarik kesimpulan secara deduktif. Hasil penelitian mengungkapkan bahwa apakah perlindungan hukum bagi pemilik tanah dalam akta jual beli tanah PPAT yang batal demi hukum oleh putusan pengadilan sudah memberikan perlindungan dan kepastian hukum.

\section{Pendahuluan}

Kepastian hukum dapat diwujudkan dengan memberikan perlindungan hukum kepada masyarakat. Satjipto Raharjo, mendefinisikan "perlindungan hukum adalah memberikan pengayoman kepada hak asasi manusia yang dirugikan orang lain dan perlindungan tersebut diberikan kepada masyarakat agar mereka dapat menikmati semua hak-hak yang diberikan oleh hukum". ${ }^{1}$ Perlindungan hukum kepada subjek hukum bersifat preventif dan represif. Tujuan perlindungan hukum preventif untuk menghindari suatu peristiwa yang menyebabkan sengketa. Tujuan perlindungan hukum represif adalah permasalahan yang timbul/ sengketa diselesaikan dengan mengajukan gugatan ke pengadilan. ${ }^{2}$

Perlindungan hukum diperlukan masyarakat dalam menggunakan tanah, baik untuk dijadikan tempat tinggal, perkantoran, lahan pertanian, perkebunan, peternakan dan lain-lain. ${ }^{3}$ Perlindungan hukum oleh negara mengenai penggunaan tanah, hak atas tanah dan peralihan kepemilikan hak atas tanah diatur dalam Undang-Undang Nomor 5 Tahun 1960 tentang Peraturan Dasar Pokok-Pokok Agraria selanjutnya disebut UUPA. Untuk itu masyarakat mengupayakan peralihan kepemilikan hak atas tanah sebagai bentuk kepastian hukum dalam memiliki tanah tertentu.

Perbuatan hukum peralihan hak atas tanah seperti jual beli tanah harus dilakukan di hadapan pejabat yang berwenang untuk memberikan jaminan kepastian hukum. Pasal 1 angka 1 PP RI No. 24 Tahun 2016, yang menyatakan bahwa: "Pejabat Pembuat Akta Tanah, selanjutnya disebut PPAT, adalah pejabat umum yang diberi kewenangan untuk membuat akta-akta autentik mengenai perbuatan hukum tertentu mengenai hak atas tanah atau hak milik atas satuan rumah susun mengenai hak atas tanah atau hak milik atas satuan rumah susun".

Notaris dapat merangkap jabatan sebagai PPAT sesuai ketentuan Pasal 7 ayat (1) PP RI No. 24 Tahun 2016. ${ }^{4}$ PPAT dan notaris sebagai pejabat umum memiliki sifat dan lingkup kegiatan yang berbeda. Di masyarakat jabatan PPAT dan notaris dianggap sama, karena membuat akta autentik, tapi secara nyata tugas dan jabatan PPAT dan notaris berbeda dan diatur dalam peraturan yang berbeda. Dalam melaksanakan tugasnya, notaris wajib menjalankan ketentuan dalam Undang-Undang Nomor 2 Tahun 2014 tentang

${ }^{1}$ Rahardjo, S. (1983). Permasalahan Hukum di Indonesia, Bandung: Alumni, h. 121.

${ }^{2}$ Lubis, M. Y. \& Lubis, R. (2008). Hukum Pendaftaran Tanah, Bandung: CV. Mandar Maju, h. 18.

${ }^{3} \mathrm{Ibid}, \mathrm{h} .18$.

4 Veronika, N. (2019). Bentuk Perlindungan Hukum Terhadap PPAT Pasca Perubahan Pasal 66 UU No. 2 Tahun 2014 tentang Jabatan Notaris. Jurnal Indonesian Notary, 1(4), h. 3. 
Perubahan Atas Undang-Undang Nomor 30 Tahun 2004 tentang Jabatan Notaris selanjutnya disebut UUJN.

Prakteknya pelaksanaan tugas dan jabatan sebagai PPAT, berkaitan langsung dengan tugas dan jabatan notaris dalam membuat akta autentik. Karena akta pertanahan yang bukan merupakan kewenangan PPAT, menjadi kewenangan notaris berdasarkan Pasal 15 ayat (2) huruf f UUJN, yang mengatakan bahwa : "membuat akta yang berkaitan dengan pertanahan". Contoh akta autentik yang berhubungan dengan pertanahan misalnya akta kuasa menjual, akta pengikatan jual beli, surat persetujuan suami/istri yang dilegalisasi oleh notaris, akta pengakuan hutang yang jaminannya berupa tanah dan lain-lain.

Pembuatan akta autentik mengenai tanah tentunya harus menerapkan prinsip kehatihatian, mempunyai kemampuan dan keahlian khusus di bidang pertanahan, membedakan kewenangan PPAT dan notaris dalam menjalankan tugas dan jabatannya dengan tujuan menghindari permasalahan hukum di kemudian hari, mengingat PPAT dan notaris membuat akta autentik sebagai alat bukti dari para pihak yang saling mengikat.

Kewenangan PPAT dalam membuat akta jual beli tanah (AJBT) harus memperhatikan ketentuan Pasal 22 PP RI No. 37 Tahun 1998 bahwa : “akta PPAT harus dibacakan/ dijelaskan kepada para pihak dengan dihadiri oleh sekurang-kurangnya dua orang saksi sebelum ditandatangani seketika itu juga oleh para pihak, saksi-saksi dan PPAT". Untuk itu pembuatan AJBT selain memperhatikan syarat sah perjanjian, PPAT bertanggung jawab menjelaskan isi akta kepada para pihak yang berkepentingan.

Prakteknya substansi atau klausula dari akta tidak selamanya dijelaskan di hadapan para pihak yang berkepentingan sehingga substansi atau klausula akta dan ketentuan lahirnya suatu akta autentik tidak dapat berjalan sesuai dengan peraturan yang berlaku. Kondisi tertentu seperti ini, apabila substansi atau klausula dari akta yang diperjanjikan tidak sesuai dengan peraturan yang berlaku, mengakibatkan terjadinya perbuatan melawan hukum. ${ }^{5}$

Akibat dari perbuatan melawan hukum, akta tersebut dapat dimohonkan pembatalannya dari salah satu pihak yang merasa dirugikan akibat lahirnya akta tersebut dimuka pengadilan, agar perjanjian para pihak batal demi hukum. "Batal demi hukum adalah ketika sesuatu menjadi tidak berlaku atau tidak sah karena menurut hukum memang begitu adanya". ${ }^{6}$ Batal demi hukum mengakibatkan akta perjanjian kembali ke keadaan semula sebelum akta diperjanjikan, dengan pengertian perjanjian tersebut tidak pernah ada. Dan berdasarkan Pasal 1265 KUH Perdata, "syarat batal adalah suatu syarat yang apabila terpenuhi, menghentikan perjanjian dan membawa segala sesuatu kembali keadaan semula seolah-olah tidak pernah terjadi perjanjian".

Adapun AJBT yang dibuat oleh PPAT dinyatakan batal demi hukum oleh pengadilan dan dijadikan bahan analisis dalam penelitian ini, yaitu :

${ }^{5}$ Widjaja, H. \& Tanawijaya, H. (2018). Analisis Perbuatan Melawan Hukum Dalam Akta Perjanjian Pengikatan Jual Beli (PPJB) Tanah Antara Koko Purnomo Santoso Dengan Pt. Intan Plaza Adika. Jurnal Hukum Adigama, 1(1), h. 4.

${ }^{6}$ Erawati, E \& Budiono, H. (2010). Penjelasan Hukum tentang Kebatalan Perjanjian. Jakarta: Nasional Legal Reform Program, h. 1. 
a. Putusan PN Ungaran tanggal 9 Mei 2016, No.80/Pdt.G/2015/PN.Unr, sehubungan dengan AJBT nomor : 268/2009 tanggal 4 November 2009, AJBT nomor : 262/2009 tanggal 3 November 2009, AJBT nomor : 261/2009 tanggal 3 November 2009, AJBT nomor : 263/2009 tanggal 3 November 2009. Semua akta tersebut dibuat di hadapan Kiagus Daus sebagai PPAT Semarang yang beralamat di Jalan Raya Karangjati No. 29, Semarang.

b. Putusan PN Tanjung Karang tanggal 19 Agustus 2015, No.35/Pdt.G/2015/PN.Tjk, sehubungan dengan AJBT nomor 564/114/TKT/2010 tertanggal 13 Desember 2010 yang dibuat di hadapan Djoni S.H., PPAT Kota Bandar Lampung yang beralamat di Jalan Ikan Hiu Blok C no. 3 Teluk Betung, Bandar Lampung.

Berdasarkan uraian kasus diatas, penelitian ini mengkaji sejauh manakah tanggung jawab PPAT terhadap AJBT yang batal demi hukum oleh putusan pengadilan dan bagaimanakah perlindungan hukum bagi pemilik tanah dalam AJBT PPAT yang batal demi hukum oleh putusan pengadilan.

Tujuan penelitian ini untuk menganalisis tanggung jawab PPAT terhadap AJBT dan menganalisis perlindungan hukum bagi pemilik tanah dalam AJBT PPAT yang batal demi hukum oleh putusan pengadilan.

\section{Metode Penelitian}

Metode penelitian yang digunakan adalah yuridis normatif dengan pendekatan perundang-undangan dan pendekatan kasus. Sumber bahan hukum dalam penelitian adalah data sekunder yang terdiri dari bahan hukum primer, bahan hukum sekunder, bahan hukum tersier yang berkenaan dengan AJBT, PPAT, notaris, hukum perdata, hukum agraria, serta yang sesuai dengan peraturan perundang-undangan, jurnal hukum dan putusan peradilan yang kemudian seluruhnya dianalisis secara kualitatif dan ditarik kesimpulan secara deduktif yang menganalisis norma hukum dalam peraturan perundang-undangan. Pengolahan bahan hukum dengan cara deduktif yaitu pengolahan bahan hukum dari sesuatu yang sifatnya umum kemudian ditarik kesimpulan secara khusus. ${ }^{7}$

\section{Hasil dan Pembahasan}

\section{Perlindungan Hukum bagi Pemilik Tanah dalam Akta Jual Beli Tanah PPAT yang Batal Demi Hukum oleh Putusan Pengadilan}

\subsection{Kewenangan PPAT dalam Mencermati AJBT}

PPAT berwenang memperhatikan hal-hal yang menjadi faktor terjadinya pembatalan AJBT, seperti: kedudukan atau status penjual dan pembeli. Penjual adalah seseorang yang berwenang menjual tanah dan pembeli adalah seseorang yang berwenang membeli tanah. ${ }^{8}$ Adapun syarat pembuatan AJBT di hadapan PPAT yaitu:

a. Data Penjual yang terdiri dari : foto kopi Identitas Kartu Tanda Penduduk (Suami/istri jika sudah menikah disertai Kartu Keluarga, Buku Nikah), sertifikat tanah asli, NPWP jika ada dan PBB dibuktikan dengan bukti pembayaran terakhir.

\footnotetext{
${ }^{7}$ Marzuki, P. M. (2011). Penelitian Hukum, Jakarta: Rajawali Pers, h. 47.

8 Wardana, R. A. \& Handayani, I. G. A. K. R. (2016). Pembatalan Akta Jual Beli Yang Cacat Hukum Dengan Putusan Pengadilan. Jurnal Repertorium, 1-15, h. 6.
} 
b. Data Pembeli yang terdiri dari : foto kopi Identitas Kartu Tanda Penduduk (Suami/istri jika sudah menikah disertai Kartu Keluarga, Buku Nikah), Nomor Pokok Wajib Pajak jika ada.

Perlu diketahui untuk setiap kelengkapan data, harus diperlihatkan aslinya di depan PPAT. Kewenangan PPAT dalam mencermati persyaratan sebelum pembuatan AJBT sangat diperlukan, seperti mencermati syarat formil yang terdiri dari :

a. Identitas Kartu Tanda Penduduk, hal-hal yang perlu diperhatikan setelah melihat status dan kewarganegaraan:

1) Untuk hak milik atas tanah yang berasal dari milik suami istri, dibuktikan dengan persetujuan suami/istri yang dilegalisasi oleh notaris. Dengan tujuan memberikan persetujuan atas pemindahan atau pembebanan hak milik atas tanah.

2) Untuk hak milik atas tanah yang berasal dari warisan, apabila WNI bukan keturunan tionghoa, menyerahkan surat ahli waris yang dibuat di camat/desa/keuchik/kelurahan dimana tempat tinggal pewaris waktu meninggal dunia. Untuk WNI keturunan tionghoa, menyerahkan akta keterangan hak mewarisi dari notaris atau berdasarkan putusan pengadilan (Pasal 111-112 Perkaban No. 3 Tahun 1997).

b. Surat Nikah, hal-hal yang harus diperhatikan :

Harus menanyakan apakah membuat perjanjian kawin, apabila tidak membuat perjanjian kawin, untuk harta yang diperoleh setelah menikah menjadi harta bersama dan untuk harta bersama tersebut harus ada persetujuan suami/istri dalam melakukan perbuatan hukum (Pasal 119 KUH Perdata). Untuk yang sudah bercerai harus menunjukkan surat cerai.

c. Menunjukkan PBB, dibuktikan dengan bukti pembayaran terakhir dan keterangan dari KPP (Kantor Pelayanan Pajak) bahwa tidak ada tunggakan PBB, apabila ada tunggakan, maka harus dilunasi terlebih dahulu sebelum membuat AJBT.

d. Bukti pembayaran PBB tersebut dipergunakan PPAT untuk mengetahui besar PPh atas pemindahan (PP RI No. 71 Tahun 2008) atau peralihan hak milik atas tanah yang dibayar penjual, dan untuk mengetahui besar pajak BPHTB yang dibayar pembeli.

Selain hal diatas, kewenangan PPAT lainnya: pada saat menerima sertifikat tanah harus melakukan pengecekan keaslian sertifikat di kantor pertanahan. Dasar hukum pengecekan sertifikat ini diatur dalam Pasal 97 ayat (1) Perkaban No. 3 Tahun 1997.

Tujuan pengecekan sertifikat adalah untuk menganalisis kebenaran formil dan kebenaran materil dari sertifikat tersebut. Dan untuk saat ini layanan pengecekan sertifikat tanah sudah dapat dilakukan melalui aplikasi online yang merupakan aplikasi resmi dari kantor pertanahan. Apabila verifikasi selesai dan benar merupakan milik penjual, maka penjual sudah bisa membayar PPh dan pembeli membayar bea perolehan hak atas tanah dan bangunan (BPHTB). Persyaratan yang sudah lengkap, akan dibuatkan AJBT, apabila persyaratan belum lengkap maka PPAT berhak menolak pembuatan AJBT. 


\subsection{AJBT PPAT yang Mengandung Cacat Hukum}

Syarat dan tata cara pembuatan AJBT sebagai akta autentik merupakan prosedur pembuatan akta yang tidak boleh menyimpang dan harus sesuai peraturan yang berlaku. Penyimpangan dari prosedur pembuatan akta mengakibatkan cacat hukum. Akta autentik yang cacat hukum dilatar belakangi oleh :

a. Persyaratan yang ditetapkan oleh UU sebagai syarat formil dalam akta tidak terpenuhi, mengakibatkan perjanjian batal demi hukum

b. Syarat sah perjanjian tidak terpenuhi. yaitu :

1) Sepakat mereka yang mengikatkan dirinya

“Dengan sepakat mengadakan perjanjian, maka berarti para pihak haruslah mempunyai kebebasan kehendak. Para pihak tidak mendapat suatu tekanan yang mengakibatkan adanya cacat bagi perwujudan kehendak tersebut" ${ }^{9}$

2) Kecakapan untuk membuat perjanjian

Subjek perjanjian terdiri dari orang dan badan hukum. Perusahaan berbadan hukum seperti PT, Perusahaan Perseroan (Persero), Koperasi, Perusahaan Umum dan bentuk badan usaha bukan berbadan hukum seperti Persatuan komanditer, Persekutuan Firma. ${ }^{10}$

Menurut Pasal 1329 KUH Perdata : "setiap orang adalah cakap untuk membuat perjanjian, kecuali jika undang-undang menyatakan bahwa orang tersebut adalah tidak cakap". "Orang-orang yang tidak cakap membuat perjanjian adalah orang-orang yang belum dewasa dan mereka yang ditaruh dibawah pengampunan. Belum dewasa adalah mereka yang belum mencapai umur 21 tahun dan belum kawin, hal ini diatur dalam Pasal 1330 KUH Perdata" 11

3) Suatu Hal Tertentu

"Undang-undang menentukan benda yang tidak dapat dijadikan objek perjanjian adalah benda yang digunakan untuk kepentingan umum". "Perjanjian harus mempunyai objek yang ditentukan jenisnya" diatur dalam Pasal 1333 KUH Perdata. Menurut Pasal 1332 KUH Perdata "hanya barang yang dapat diperdagangkan saja dapat menjadi pokok suatu perjanjian". Pasal 1334 KUH Perdata menyebutkan "barang-barang yang baru akan ada, di kemudian hari dapat menjadi pokok suatu perjanjian".

4) Suatu Sebab yang Halal

Pengertian suatu sebab yang halal ialah bukan hal yang menyebabkan perjanjian, tetapi isi perjanjian itu sendiri. "Isi perjanjian tidak boleh

\footnotetext{
9 Badrulzaman, M. A. (2001). Kompilasi Hukum Perikatan. Jakarta: PT Citra Aditya Bakti, h. 73. 10 Azhari. (2018). Hukum Bisnis dalam Era Globalisasi. Banda Aceh: Percetakan Bandar, h. 129.

11 Ibid, h. 78.
} 
bertentangan dengan undang-undang, kesusilaan maupun ketertiban umum" dalam Pasal 1337 KUH Perdata. ${ }^{12}$

c. Untuk perjanjian bersyarat, syarat batal terpenuhi

d. Pembatalan pihak ketiga atas dasar action paulina.

Prakteknya dalam pembuatan AJBT yang dibuat oleh PPAT, penyimpangan dan pelanggaran yang merugikan para pihak yang bersangkutan dalam kontruksi AJBT 13 yaitu :

a. Penandatanganan AJBT oleh para pihak dilakukan sebelum melakukan cek bersih di kantor pertanahan. Tujuan cek bersih untuk memperoleh kepastian dari data fisik dan data yuridis sertifikat yang bersangkutan sesuai ketentuan dalam Pasal 97 ayat (5) Perkaban No. 3 Tahun 1997. Berdasarkan ketentuan tersebut, PPAT memastikan bahwa sertifikat bersangkutan adalah sertifikat yang diterbitkan oleh kantor pertanahan, memastikan bahwa data fisik dan data yuridis sesuai dengan yang tercatat dalam buku tanah kantor pertanahan, memastikan bahwa hak milik atas tanah tidak dalam perkara, dibebani hak tanggungan dan beban lainnya.

b. Pengecekan sertifikat hanya dengan cek lisan

c. Penandatanganan AJBT ditandatangani lebih dulu, sebelum penjual membayar PPh dan pembeli membayar lunas harga transaksi jual beli tanah disertai pembayaran BPHTB.

d. PPAT tidak membacakan AJBT di hadapan para pihak secara rinci hanya garis besar dalam akta saja

e. Penandatangan AJBT tidak dilakukan bersamaan antara para pihak yang bersangkutan

f. Nilai transaksi yang dituangkan dalam AJBT tidak sesuai dengan nilai transaksi yang sebenarnya dan

g. Saksi tidak terlibat secara langsung dalam proses penandatangan akta, dan pembuatan AJBT dilakukan tanpa dihadiri saksi dan dilakukan diluar daerah kerja PPAT.

Selain penyimpangan terhadap syarat materil (baik subjek dan objeknya) dalam AJBT, penyimpangan AJBT dalam prakteknya juga terjadi terhadap syarat formil (prosedur dan persyaratan) pembuatan akta tersebut ${ }^{14}$ yaitu :

a. Penyimpangan dapat terjadi karena salah satu pihak dalam AJBT belum cakap bertindak dalam melakukan perbuatan hukum artinya salah satu pihak belum cukup umur (dibawah 21 tahun) dan belum menikah, ketentuan ini diatur dalam Stbl 1931 No. 54. dan Pasal 330 KUH Perdata : "seseorang dianggap sudah dewasa jika sudah berusia 21 tahun atau sudah (pernah) menikah."

12 Prodjodikoro \& Wirjono, R. (2004). Asas-Azas Hukum Perjanjian. Bandung: Mandar Maju, h. 31.

13 Prawira, I. G. B. Y. (2016). Tanggung Jawab PPAT Terhadap Akta Jual Beli Tanah. Jurnal IUS, 4(1), h. 69.

14 Faridah, U. \& Suryandono, W. (2019). Perlindungan Hukum Terhadap Penjual Atas Jual Beli Tanah Yang Cacat Hukum Dan Notaris/PPAT Yang Telah Meninggal Dunia. Jurnal Notary Indonesian, 1(2), h. 9. 
b. Penyimpangan karena penghadap bertindak atas dasar kuasa, namun pemberi kuasa dalam akta kuasa telah meninggal dunia. Sesuai ketentuan Pasal 1813 KUH Perdata yaitu: "pemberian kuasa berakhir dengan penarikan kembali kuasa penerima kuasa, dengan pemberitahuan penghentian kuasanya oleh penerima kuasa, dengan meninggalnya pengampunan atau pailitnya, baik pemberi kuasa maupun penerima kuasa".

Penghadap bertindak berdasarkan hak substitusi, dan dicantumkan dalam akta pemberian kuasa mengenai hak substitusi tersebut, agar tidak melampaui batas, karena sifat pemberian kuasa adalah persetujuan. Untuk itu si penghadap atau penerima kuasa tidak boleh bertindak melampaui persetujuan dalam kuasa yang diterimanya, hal ini diatur dalam Pasal 1719 KUH Perdata yaitu: "Penerima titipan tidak boleh mengembalikan barang titipan itu selain kepada orang yang menitipkan sendiri barang itu atau kepada orang yang atas namanya menitipkan barang itu, atau kepada wakil yang ditunjuknya untuk menerima kembali barang termaksud".

c. Penyimpangan dilakukan oleh pihak penjual yang tidak mengikutsertakan pihakpihak yang berhak memberi persetujuan atas perbuatan hukum dalam akta tersebut. Seperti :

1) tidak mengikutsertakan persetujuan suami/istri, dalam melakukan perbuatan hukum atas AJBT kepemilikan sebagai harta bersama selama pernikahan, maka diharuskan adanya persetujuan suami/istri. Pasal 119 KUH Perdata: “Mulai saat perkawinan dilangsungkan, demi hukum berlakulah persatuan harta secara bulat antara kekayaan suami dan istri, sekadar mengenai hal itu dengan perjanjian kawin tidak diadakan ketentuan lain".

2) tidak mengikutsertakan persetujuan dari pengurus perseroan atau pengurus yayasan/ koperasi lainnya, terhadap pengurus perseroan atau pengurus yayasan/ koperasi yang melakukan perbuatan mengalihkan atau menjaminkan hak atas tanah yang merupakan harta kekayaan perseroan tanpa persetujuan pesero lainnya atau pengurus yayasan / koperasi lainnya yang ditetapkan dalam anggaran dasar.

Prakteknya dalam pembuatan AJBT yang dibuat oleh PPAT, penyimpangan dan pelanggaran yang merugikan para pihak yang bersangkutan menimbulkan akibat hukum, dan pihak yang merasa dirugikan meminta pembatalannya dimuka pengadilan. Apabila PPAT terbukti melakukan penyimpangan dan pelanggaran, maka PPAT tersebut harus memberikan pertanggungjawaban. Akta autentik yang dibuat PPAT dan mengandung cacat hukum baik disengaja atau tidak sengaja, maka akta autentik tersebut hanya mempunyai kekuatan sebagai akta dibawah tangan. Dan penyebab permasalahan lainnya juga ketidakjujuran para pihak yang menghadap ke PPAT atas kebenaran syarat pembuatan AJBT yang berakibat akta batal demi hukum setelah di mintakan pembatalannya ke pengadilan.

\subsection{Pertanggungjawaban PPAT terhadap AJBT}

Unsur yang terkandung di dalam teori pertanggungjawaban hukum yaitu teori tanggung jawab, dan hukum itu sendiri. Bentuk dasar dari kata "tanggung jawab" mendapat awalan "per" serta akhiran "an" sehingga menjadi "pertanggungjawaban", 
artinya suatu perbuatan bertanggung jawab atau sesuatu perbuatan yang dipertanggungjawabkan. ${ }^{15}$ Menurut Henry Campbell Black, bahwa terdapat dua istilah pertanggungjawaban, yaitu liability dan responsibility. Liability merupakan istilah hukum yang luas, yang mengandung makna : "It has been referred to as of the most comprehensive significance, including almost every character of hazard or responsibility, absolute, contingent, or likely. It has been defined to mean: all character of debts and obligations". 16

Maksudnya liability bermakna komprehensif (luas dan lengkap), termasuk hampir setiap karakter resiko atau tanggung jawab, yang mutlak, yang bergantung atau yang mungkin terjadi. Liability ini didefinisikan untuk menunjuk pada semua karakter hak dan kewajiban. Sedangkan responsibility merupakan kewajiban untuk bertanggung jawab atas tindakan yang dilakukan dan untuk memperbaiki atau membayar kerugian atas kerusakan yang mungkin telah dilakukan. "The obligation to answer for an act done, and to repair or otherwise make restitution for any injury it may have caused"17. Antara kedua istilah ini, istilah liability yang sering dipakai dalam menunjuk pada pertanggung jawaban hukum yakni tanggung gugat akibat kesalahan yang dilakukan oleh subjek hukum, sedangkan istilah responsibility lebih menunjuk pada pertanggung jawaban politik ${ }^{18}$.

Teori pertanggungjawaban hukum digunakan untuk menganalisis apa saja sanksi yang dapat dibebankan kepada PPAT sebagai pejabat umum negara yang memiliki kewenangan membuat akta pertanahan. Pada saat PPAT menjalankan tugas dan jabatannya dalam membuat akta autentik berkaitan dengan tanah khususnya AJBT, ada kalanya dalam pembuatan AJBT tersebut terdapat kesalahan. Kesalahan tersebut bisa karena menyangkut persyaratan formil dan persyaratan materil, ataupun kesalahan PPAT yang berakibat akta autentik tersebut menjadi akta dibawah tangan dan tidak menjadi alat bukti yang sempurna bagi para pihak yang berkepentingan dan hal ini dapat dilakukan karena unsur sengaja dan unsur tidak sengaja oleh PPAT.

Pertanggungjawaban yang diminta kepada PPAT bukan hanya pertanggungjawaban terhadap akta tetapi dalam arti luas yaitu pertanggungjawaban pada saat akta berlangsung dan pertanggungjawaban pada saat pasca penandatanganan akta. Untuk itu PPAT harus dengan cermat dan benar dalam memproses tahapan pembuatan AJBT baik dalam syarat formil dan syarat materil, yaitu :

a. Syarat formil

1) Harus mencermati dan menjalankan Pasal 97 ayat (1) Perkaban No. 3 Tahun 1997.

2) Membuat akta sesuai bentuk akta yang telah ditentukan dalam peraturan dan tata cara pengisian ditentukan dalam lampiran, diatur dalam Pasal 96 Perkaban No. 8 Tahun 2012.

3) Izin pemindahan hak harus diperoleh sebelum akta pemindahan atau pembebanan hak yang bersangkutan dibuat, diatur dalam Pasal 98 ayat (2) Perkaban No. 3 Tahun 1997.

\footnotetext{
${ }^{15}$ Alwi, H. (1998).Kamus Besar Bahasa Indonesia, Jakarta: Balai Pustaka, h. 1139.

${ }^{16}$ Ridwan H.R. (2003). Hukum Administrasi Negara, Yogyakarta: UII Press, h. 249.

17 Ridwan H.R, Op.Cit, h. 249.

18 Salim HS dan Nurbani, E. S. (2017). Penerapan Teori Hukum pada Penelitian Tesis dan Disertasi, Jakarta: PT. Raja Grafindo Persada, h. 208.
} 
4) Pembuatan akta harus dihadiri oleh para pihak yang bersangkutan atau dikuasakan dengan surat tertulis sesuai peraturan yang berlaku, dan disaksikan oleh dua orang saksi yang memenuhi syarat untuk bertindak sebagai saksi dalam suatu perbuatan hukum, PPAT wajib membacakan akta, menjelaskan isi dan maksud akta kepada pihak yang bersangkutan dan memberi penjelasan prosedur pendaftaran selanjutnya yang harus dilaksanakan, sesuai aturan dalam Pasal 101 Perkaban No. 3 Tahun 1997.

5) PPAT dilarang membuat akta, "apabila PPAT sendiri, suami atau istrinya, keluarganya sedarah atau semenda, dalam garis lurus tanpa pembatasan derajat dan dalam garis ke samping sampai derajat kedua, menjadi pihak dalam perbuatan hukum yang bersangkutan, baik dengan cara bertindak sendiri maupun melalui kuasa, atau menjadi kuasa dari pihak lain", diatur dalam Pasal 23 ayat (1) PP RI No. 37 Tahun 1998 tentang PJPPAT.

6) PPAT wajib menyampaikan akta yang telah dibuatnya ke kantor pertanahan selambatnya 7 hari kerja, Pasal 40 ayat (1) PP RI No. 24 Tahun 1997.

7) PPAT menandatangani akta pemindahan hak atas tanah setelah wajib pajak menyerahkan bukti pembayaran pajak, diatur dalam Pasal 91 ayat (1) UU No. 28 Tahun 2009.

b. Syarat Materil

1) Apakah penjual berhak menjual hak milik atas tanah tersebut

2) Apakah pembeli berhak membeli objek tanah yang bersangkutan

3) Apakah para pihak bertindak sebagai diri sendiri atau sebagai kuasa

4) Apakah tanah boleh diperjualbelikan dan tidak dalam sengketa.

Dalam praktiknya, masih terdapat PPAT yang melakukan kelalaian atau kurang cermat dan teliti dalam membuat AJBT yang mengakibatkan AJBT tersebut di mintakan pembatalannya ke pengadilan oleh salah satu pihak yang merasa dirugikan atas terbitnya AJBT tersebut. PPAT yang bersangkutan diikutsertakan menjadi tergugat dalam perkara perdata dan untuk PPAT yang bersangkutan harus bertanggung jawab atas akta yang dibuatnya dan membuktikan kesalahan yang dituduhkan kepadanya.

Cacat hukum dalam akta PPAT dapat disebabkan oleh penyimpangan terhadap syarat formil dan penyimpangan terhadap syarat materil. ${ }^{19}$ Suatu objek dalam akta dapat dikatakan mengandung unsur perbuatan melawan hukum apabila yaitu "perbuatan yang dibuat bertentangan dengan hak orang lain, perbuatan yang dibuat bertentangan dengan kewajibannya sendiri, perbuatan yang dibuat bertentangan dengan kesusilaan, perbuatan yang dibuat bertentangan dengan kehati-hatian atau keharusan dalam pergaulan masyarakat yang baik" .20

Untuk PPAT harus membuktikan bahwa akta tersebut benar dibuat di hadapannya, apabila tidak bisa membuktikan bahwa akta tersebut benar dibuat di hadapan PPAT, maka syarat sah perjanjian tidak terpenuhi dan melanggar peraturan perundangundangan. Apabila PPAT tidak cermat dan teliti dalam membuat AJBT dan telah

19 Wibawa, K. D. C. S. (2009). Menakar Kewenangan dan Tanggung Jawab Pejabat Pembuat Akta Tanah (PPAT) dalam Prespektif Bestuurs Bevoegheid. Jurnal Crepido, 1(1), h. 48.

${ }^{20}$ Fuady, M. (2001). Hukum Kontrak (Dari Sudut Pandang Hukum Bisnis), Bandung: Citra Aditya Bakti, h. 6. 
melakukan perbuatan melawan hukum, atas dasar tersebut PPAT yang bersangkutan dapat di mintakan pertanggungjawabannya. Dalam mempertanggungjawabkan perbuatannya PPAT dapat bertanggung jawab secara perdata, pidana, dan administratif sesuai dengan pelanggaran yang diperbuatnya.

Pertanggungjawaban PPAT secara administratif ditentukan dalam Pasal 62 PP No. 24 Tahun 1997 dan dipertegas dalam Pasal 10 PP No. 24 Tahun 2016. Pertanggungjawaban PPAT akibat dari kesengajaan, kelalaian dan kealpaan dalam pembuatan akta pertanahan khususnya akta jual beli tanah yang menyimpang dari syarat formil dan syarat materil dalam prosedur pembuatan akta pertanahan dikenakan sanksi administratif. ${ }^{21}$

PPAT yang membuat akta tersebut akibat kelalaiannya dapat diberhentikan oleh Menteri apabila terbukti bersalah melakukan perbuatan melawan hukum berdasarkan Pasal 10 PP RINo. 24 Tahun 2016 yaitu : diberhentikan dengan hormat, diberhentikan dengan tidak hormat, diberhentikan sementara. Ketentuan lebih lanjut dalam Pasal 10 ayat (4) huruf c PP RUNo. 24 Tahun 2016, menyatakan bahwa : PPAT diberhentikan sementara karena melakukan pelanggaran ringan terhadap larangan atau kewajiban sebagai PPAT. Dan Pasal 10 ayat (3) PP RI No. 24 Tahun 2016, menyatakan bahwa PPAT diberhentikan dengan tidak hormat, karena "melakukan pelanggaran berat terhadap larangan atau kewajiban sebagai PPAT dan dijatuhi pidana penjara berdasarkan putusan pengadilan yang telah memperoleh kekuatan hukum tetap karena melakukan tindak pidana yang diancam dengan pidana penjara lima tahun atau lebih".

Konstruksi yuridis yang digunakan dalam pertanggungjawaban PPAT secara perdata adalah konstruksi perbuatan melawan hukum. Teori pertanggungjawaban hukum dalam KUH Perdata dijelaskan dalam Pasal 1365 KUH Perdata yaitu "tiap-tiap perbuatan melanggar hukum, yang membawa kerugian kepada orang lain, mewajibkan orang yang karena salahnya menerbitkan kerugian itu, mengganti kerugian tersebut". Dengan demikian, pasal tersebut digunakan sebagai dasar untuk menyatakan PPAT dinyatakan melakukan perbuatan melawan hukum atas lahirnya akta pertanahan.

Akibat perbuatan melawan hukum yang dilakukan PPAT apabila terbukti bersalah berdasarkan kebenaran formil dari akta autentik yang dibuktikan di muka pengadilan oleh hakim maka PPAT harus mempertanggungjawabkan perbuatannya. Yang bertujuan memberikan kepastian kepada para pihak yang dirugikan atas perbuatan melawan hukum yang dilakukan PPAT dalam pembuatan akta autentik. Unsur adanya perbuatan melawan hukum adalah terdapat kesalahan yang berkaitan dengan melawan hukum dan kerugian atas hal tersebut ditanggung orang lain.

Pertanggungjawaban PPAT secara pidana tidak dijelaskan dalam UUJN maupun peraturan jabatan PPAT, namun sanksi pidana dikenakan apabila PPAT melakukan perbuatan yang melanggar hukum dan sanksi pidana berdasarkan KUH Pidana. Penjatuhan sanksi pidana kepada PPAT biasanya dikarenakan PPAT mengetahui terdapat surat palsu ataupun PPAT memalsukan surat (Pasal 263 KUH Pidana), memalsukan akta autentik (Pasal 264 KUH Pidana), memasukkan keterangan palsu yang diketahui PPAT (Pasal 266 KUH Pidana) dan perbuatan lainnya dengan ketentuan termasuk dalam unsur pidana.

${ }^{21}$ Prawira, I. G. B. Y. Op.cit, h. 69. 


\subsection{Perlindungan Hukum bagi Pemilik Tanah terhadap AJBT PPAT yang Batal Demi Hukum}

Perlindungan hukum menurut Satjipto Rahardjo, adalah "upaya melindungi kepentingan seseorang dengan cara mengalokasikan suatu kekuasaan kepadanya untuk bertindak dalam rangka kepentingan tersebut". ${ }^{22}$ Harjono berpendapat "perlindungan yang diberikan oleh hukum merupakan perlindungan atas hak masyarakat yang merupakan hasil transformasi kepentingannya, yang selanjutnya menjadi hak hukum, sehingga hak masyarakat dapat dihormati, dilindungi dan dipatuhi". ${ }^{23}$

Teori perlindungan hukum terhadap para pihak dalam perjanjian dapat dilakukan dengan cara melalui perlindungan hukum preventif dan represif. Perlindungan hukum preventif adalah bentuk perlindungan hukum kepada masyarakat dengan memberikan kesempatan mengajukan keberatan atau pendapatnya sebelum keputusan dari pemerintah mendapat bentuk definitf, tujuannya untuk mencegah terjadinya sengketa atau pelanggaran di kemudian hari serta memberikan ramburambu atau batasan dalam melakukan suatu kewajiban. Perlindungan hukum represif adalah perlindungan akhir berupa denda, penjara dan hukuman tambahan yang diberikan apabila sudah terjadi sengketa atau telah dilakukan pelanggaran. ${ }^{24}$

Perlindungan hukum bagi pemilik tanah diberikan oleh negara agar memperoleh kepastian hukum. Negara menjamin kepastian hukum dalam hal pendaftaran tanah diatur dalam Pasal 19 ayat (1) UUPA dan berdasarkan hal tersebut Pasal 19 ayat (2) UUPA menjelaskan: "pendaftaran tanah tersebut meliputi pengukuran, perpetaan dan pembukuan tanah, pendaftaran hak-hak atas tanah dan peralihan hak-hak atas tanah, pemberian surat-surat tanda bukti hak, yang berlaku sebagai alat pembuktian yang kuat". Hal ini menjelaskan bahwa pendaftaran tanah menghasilkan surat tanda bukti hak yang berlaku sebagai alat bukti.

Surat tanda bukti hak yang dimaksud berupa sertifikat tanah di tuangkan dalam Pasal 32 PP RI No. 24 Tahun 1997 yang menyatakan bahwa:

a. Sertifikat merupakan surat tanda bukti hak yang berlaku sebagai alat pembuktian yang kuat mengenai data fisik dan data yuridis yang termuat di dalamnya, sepanjang data fisik dan data yuridis tersebut sesuai dengan data yang ada dalam surat ukur dan buku tanah hak yang bersangkutan.

b. Dalam hal atas suatu bidang tanah sudah diterbitkan sertifikat secara sah atas nama orang atau badan hukum yang memperoleh tanah tersebut dengan itikad baik dan secara nyata menguasainya, maka pihak lain yang merasa mempunyai hak atas tanah itu tidak dapat lagi menuntut pelaksanaan hak tersebut apabila dalam waktu 5 (lima) tahun sejak diterbitkannya sertifikat itu tidak mengajukan keberatan secara tertulis kepada pemegang sertifikat dan Kepala Kantor Pertanahan yang bersangkutan ataupun tidak mengajukan gugatan ke Pengadilan mengenai penguasaan tanah atau penerbitan sertifikat tersebut.

22 Rahardjo, S. (2003). Sisi-sisi Lain dari Hukum di Indonesia, Jakarta: Kompas, h. 121.

${ }^{23}$ Harjono, (2008). Konstitusi Sebagai Rumah Bangsa, Jakarta: Konstitusi Press, h. 375.

${ }^{24}$ Hadjon, P. M. (1987).Perlindungan Rakyat Bagi Rakyat di Indonesia (sebuah Studi tentang PrinsipPrinsipnya, Penanganannya oleh Pengadilan dalam Lingkungan Peradilan Umum dan Pembentukan Peradilan Administrasi Negara), Surabaya: PT. Bina Ilmu, h. 40. 
Sertifikat tanah adalah "dokumen formal yang memuat data yuridis dan data fisik yang dipergunakan sebagai tanda bukti dan alat pembuktian bagi seseorang atau badan hukum atas suatu bidang tanah yang dikuasai atau dimiliki dengan suatu hak atas tanah tertentu". ${ }^{25}$ Berdasarkan hal tersebut, untuk menjamin kepastian hukum bagi pemilik objek tanah diberikan sertifikat yang sudah didaftarkan sebagai alat bukti yang kuat sesuai dengan Pasal 4 PP RI No. 24 Tahun 1997.

Apabila di kemudian hari terdapat "tuntutan atau gugatan hukum di pengadilan atas objek tanah yang telah diterbitkan sertifikatnya, maka semua keterangan yang terdapat dalam sertifikat hak milik tersebut mempunyai kekuatan pembuktian yang kuat sepanjang tidak ada bukti lain yang mengingkarinya". ${ }^{26}$ Dalam penyelesaian perkara perdata di pengadilan, seorang hakim memimpin persidangan harus bersikap adil dan tidak memihak ke salah satu pihak. Begitu juga ketika agenda pembuktian di persidangan berlangsung, hakim harus memberikan kesempatan yang seimbang kepada para pihak untuk mengajukan alat buktinya. pembuktian merupakan salah satu prosedur tahapan penyelesaian sengketa antara para pihak.

Menurut Sudikno Mertokusumo, pembuktian mengandung makna logis, yuridis dan konvensional. Maksud dari logis yaitu memberikan kepastian yang mutlak. Maksud dari yuridis yaitu memberi dasar yang cukup kepada hakim yang memeriksa perkara yang bersangkutan guna memberi kepastian tentang kebenaran peristiwa yang di ajukan. Maksud dari konvensional yaitu kepastian tetapi bukan kepastian mutlak. Sedangkan menurut Subekti "hukum pembuktian adalah meyakinkan hakim tentang kebenaran dalil-dalil yang dipersengketakan di persidangan" ${ }^{27}$

Berkaitan dengan beban pembuktian tersebut merujuk pada ketentuan dalam Pasal 1865 KUH Perdata yaitu : "setiap orang yang mengaku mempunyai suatu hak atau menunjuk suatu peristiwa untuk meneguhkan haknya itu atau untuk membantah suatu hak orang lain, wajib membuktikan adanya hak itu atau kejadian yang dikemukan itu". Pasal tersebut sejalan dengan Pasal 163 Herziene Inlandsch Reglement (HIR) yang menegaskan : "barang siapa yang mengatakan ia mempunyai hak atau ia menyebut sesuatu perbuatan untuk menguatkan haknya itu atau untuk membantah hak orang lain, maka orang itu harus membuktikan adanya hak itu atau adanya kejadian itu".

Berdasarkan hal tersebut, untuk meneguhkan haknya dan membantah dalil lawan dalam persidangan yang terjadi antara para pihak harus berdasarkan alat bukti yang sah dan diajukan sesuai peraturan perundang-undangan. Alat bukti yang digunakan dalam pembuktian perkara perdata diatur dalam ketentuan Pasal 164 HIR, Pasal 284 RBG dan Pasal 1866 KUH Perdata yaitu : "bukti surat, bukti saksi, persangkaan, pengakuan dan sumpah". ${ }^{28}$

${ }^{25}$ Paidawati, N. W. P. \& Suharta, I. N. (2016). Sifat Pembuktian Sertifikat Sebagai Tanda Bukti Hak Berdasakan Ketentuan Peraturan Pemerintah Nomor 24 Tahun 1997 tentang Pendaftaran Tanah. Jurnal Kertha Semaya, 4(3), h. 3.

26 Krisnawati, I. G. A. A. A. (2015). Pembuktian Perkara Perdata. Diklat Kuliah, h. 3.

27 Krisnawati, I. G. A. A. A. Op.cit, h. 4.

28 Soeikromo, D. (2014). Proses Pembuktian dan Penggunaan ALat-Alat Bukti Pada Perkara Perdata di Pengadilan. Jurnal Unsrat, 2(1), h. 127. 
Alat bukti surat merupakan alat bukti yang utama dalam perkara perdata. untuk menguatkan perbuatan perdata yang sengaja dilakukan, perlu adanya bukti yang jelas dan pasti, sehingga alat bukti yang paling mudah untuk membuktikan terjadinya perbuatan perdata adalah dalam bentuk tulisan. ${ }^{29}$ Sertifikat tanah sebagai alat bukti surat tertulis merupakan alat pembuktian yang kuat untuk memperoleh kepastian hukum. Berkaitan dengan hal tersebut, yang dapat dibuktikan dalam sertifikat tanah yaitu :

a. Jenis hak atas tanah, kebenaran mengenai jenis hak atas tanahnya yaitu benar sertifikat hak milik atau jenis sertifikat lainnya seperti sertifikat hak guna usaha, sertifikat hak guna bangunan, sertifikat hak penguasaan tanah dll.

b. Kebenaran pemegang haknya

c. Keterangan fisik tentang objek tanahnya

d. Peristiwa hukum yang terjadi dengan objek tanahnya.

Dengan demikian keterangan dalam sertifikat tanah mempunyai kekuatan pembuktian yang kuat untuk dibuktikan dalam persidangan sepanjang tidak ada bukti lain yang mengingkarinya.

PP RI No. 24 Tahun 1997 mengenai pendaftaran tanah menggunakan sistem publikasi negatif, artinya negara hanya secara pasif menerima apa yang dinyatakan oleh pihak yang menerima pendaftaran. Akibat dari hal tersebut apabila di kemudian hari adanya gugatan terhadap objek tanah karena merasa berhak atas tanah tersebut maka pihak yang memperoleh tanah, dari orang yang terdaftar tidak terjamin walaupun diperoleh berdasarkan itikad baik. ${ }^{30}$ Ciri-ciri sistem publikasi negatif dalam pendaftaran tanah ${ }^{31}$ sebagai berikut :

a. Akta pemindahan hak dibukukan dalam daftar umum dan memiliki kekuatan hukum

b. Sesuatu hal yang tidak diumumkan tidak diakui

c. Publikasi bukan berarti suatu hak sudah beralih, yang berhak untuk mendapatkan hak dalam akta, belum tentu menjadi pemilik yang sebenarnya

d. Pendaftaran tanah bukan merupakan jaminan terhadap nama yang terdaftar dalam buku tanah

e. Pemegang hak tidak kehilangan hak tanpa perbuatannya sendiri

Berdasarkan hal tersebut, sertifikat hak milik yang tercatat dalam buku tanah di kantor pertanahan masih bisa berubah, sepanjang kepemilikan tanah tersebut dapat dibuktikan dan diputuskan melalui putusan pengadilan yang berkekuatan hukum tetap.

Kelebihan sistem publikasi negatif yaitu: adanya perlindungan kepada pemilik sertifikat yang sebenarnya, dan adanya penyelidikan terhadap riwayat objek tanah sebelum sertifikat diterbitkan. Kelemahan sistem publikasi negatif yaitu pihak yang namanya tercantum dalam sertifikat sebagai pemilik tanah dan tercatat dalam buku

29 Krisnawati, I. G. A. A. A. Op.cit, h. 4.

30 Rizqi, A. A. \& Yusriyadi. (2018). Perlindungan Hukum Pemilik Sertifikat Hak Atas Tanah Dalam Hal Terjadi Kesalahan Data Penerbitannya. Notarius, 11(3), h. 147.

31 Hadisiswati, I. (2014). Kepastian Hukum dan Perlindungan Hukum Hak Atas Tanah", Ahkam. 2(1), h. 137. 
tanah kantor pertanahan, masih dapat di ganggu gugat oleh pihak lain dengan cara menggugat ke pengadilan karena merasa memiliki dan menguasai tanah tersebut. ${ }^{32}$

Untuk menjamin dan memberikan perlindungan hukum kepada pemilik sertifikat, di dalam penjelasan PP RI Nomor 24 Tahun 1997 ditegaskan bahwa pendaftaran tanah dengan sistem publikasi negatif masih mengandung unsur positif karena akan menghasilkan surat-surat tanda bukti hak yang berlaku sebagai alat pembuktian yang kuat. Unsur positif tersebut yaitu PPAT diberikan tugas untuk meneliti secara materil dokumen yang diserahkan dan apabila tidak sesuai PPAT berhak menolak pembuatan AJBT dan kantor pertanahan berhak menolak melakukan pendaftaran jika pemilik tidak mempunyai wewenang mengalihkannya 33

Terhadap kepemilikan sertifikat tanah dapat diperkuat dengan putusan MA tanggal 18 September 1975 Nomor 459K/Sip/1975 yang menentukan "mengingat stelsel negatif tentang register/pendaftaran tanah yang berlaku di Indonesia, maka pendaftaran tanah seseorang di dalam register bukanlah berarti absolut menjadi pemilik tanah tersebut apabila ketidakabsahannya dapat dibuktikan oleh pihak lain". ${ }^{34}$

Hal ini memberikan perlindungan hukum kepada pemilik sertifikat tanah yang sebenarnya akibat dari kecurangan dan ketidakjujuran dalam perbuatan hukum yang dilakukan oleh pihak tertentu. Berkaitan dengan hal tersebut terhadap Putusan PN Ungaran No.80/Pdt.G/2015/PN.Unr.. Perlindungan hukum kepada pemilik sertifikat tanah yang sebenarnya dapat dilakukan dengan menganalisis riwayat tanah yang sebenarnya dengan bukti yang nyata. Karena pendaftaran tanah di Indonesia menganut sistem publikasi negatif.

Berdasarkan bukti dari penggugat Budi Darsono dan Lusiana empat bidang tanah yang menjadi objek terperkara dibeli dari Sodin dan Tuminah dibuktikan dengan sebagai berikut :

a. Surat Pernyataan Jual Beli 16 April 2014 yang dinyatakan oleh Sodin dan Tuminah sebagai penjual dan diketahui oleh Kepala Desa Kenteng.

b. Surat Pernyataan dari Utaya selaku mantan Kepala Desa Kenteng yang diketahui oleh Nurtati Kepala Desa Kenteng.

c. Surat Kuasa dari Budi Darsono kepada notaris untuk mengurus permohonan pengukuran tanah.

d. Surat Kuasa dari Lusiana kepada notaris untuk mengurus permohonan pengukuran tanah.

Bukti tersebut di arsip dalam dokumen tanah yang ada pada kantor desa kenteng. Dan tidak terdapat bukti atau arsip yang menyatakan bahwa tergugat Yuliana Sri Kristianingsih telah melakukan peralihan tanah dari penggugat yang terjadi tahun 1996 kepada Yuliana Sri Kristianingsih. Dan berdasarkan pengakuan Yuliana Sri Kristianingsih, Budi Darsono dan Lusiana telah menjual tanah-tanah tersebut kepada Sodikin alias Agus Sodikin secara dibawah tangan. Pengakuan tergugat Yuliana Sri

\footnotetext{
32 Ibid, h. 137.

${ }^{33}$ Yusriyadi, AAR. (2018). Perlindungan Hukum Pemilik Sertifikat Hak Atas Tanah Dalam Hal Terjadi Kesalahan Data Penerbitannya. Notarius, 11(3), h. 149.

34 Bur, A. \& Apriani, D. (2017). Sertifikat Sebagai Alat Pembuktian Yang Kuat Dalam Hubungannya Dengan Sistem Publikasi Pendaftaran Tanah. Jurnal UIR Law Review, 1(2), h. 134.
} 
Kristianingsih tidak dapat dibuktikan dengan bukti yang nyata. Dan riwayat yang tidak tercatat.

Riwayat tanah yang tercatat di dokumen kantor desa kenteng, berdasarkan pengakuan kepala desa kenteng yang menjabat pada saat itu bahwa fakta yang tercatat dalam buku desa kenteng kecamatan bandungan, asal usul empat bidang tanah terperkara berasal dari C Desa Kenteng Sodin No. 1395 dan Tuminah C Desa Kenteng No. 1396.

C Desa Sodin dan Tuminah beralih C Desa 1489 atas nama Budi Darsono dan C Desa 1490 atas nama Lusiana. Hal ini menguatkan kepemilikan sertifikat tanah yang sebenarnya. Dan untuk sertifikat hak milik yang sudah menjadi atas nama Yuliana Sri Kristianingsih dibatalkan dan kembali menjadi milik Budi Darsono dan Lusiana. Untuk itu perlindungan hukum yang diberikan kepada pemilik sertifikat yang sebenarnya dapat dibuktikan berdasarkan riwayat tanahnya yang tercatat dan memiliki saksi menjadi bukti apabila dipersidangan selanjutnya masih di sengketakan.

Demikian juga dengan kasus kedua, dalam Putusan PN Tanjung Karang No.35/Pdt.G/2015/PN.Tjk, sehubungan dengan AJBT nomor 564/114/TKT/2010 tertanggal 13 Desember 2010 yang dibuat dihadapan Djoni S.H., PPAT Kota Bandar Lampung. Perlindungan hukum kepada pemilik sertifikat yaitu Lina berdasarkan riwayat tanah dan saksi, sehingga di pengadilan dapat membuktikan kebenaran atas kepemilikan tanah.

Sertifikat Hak Milik No:11975/Kdm, Surat ukur No: 170/Kdm/2000 tanggal 28 September 2001 yang telah terdaftar atas nama Amin pada tanggal 31 Januari 2007 adalah milik harta bersama antara Amin dan Lina/ istri pertama yang belum pernah dibagi, dari keterangan saksi yaitu Gunawan Ahmad Yani dan Kartika Sari yang pada pokoknya menerangkan bahwa antara Amin dan Lina adalah suami istri yang menikah pada tahun 1999, bahwa dari perkawinan tersebut tidak dikaruniai anak.

Selama perkawinan Amin dan Lina telah membeli rumah di Perumahan Tanjung Damai Lestari Blok P No.4 kota Bandar Lampung yang sekarang ditempati Lina, bahwa harta bersama tersebut belum pernah dibagi setelah bercerai di tahun 2009 . Berdasarkan riwayat tanah tersebut jelaslah bahwa objek terperkara milik harta bersama antara Amin dan Lina.

Pengaturan mengenai harta bersama apabila tidak ada perjanjian kawin diatur dalam Pasal 119 KUH Perdata: “Mulai saat perkawinan dilangsungkan, demi hukum berlakulah persatuan harta secara bulat antara kekayaan suami dan istri, sekadar mengenai hal itu dengan perjanjian kawin tidak diadakan ketentuan lain". Kemudian dijelaskan dalam Pasal 36 ayat (1) Undang-Undang Nomor 1 Tahun 1974 tentang Perkawinan (UU No. 1 Tahun 1974), yang menyebutkan bahwa : "suami istri dapat bertindak atas harta bersama dengan persetujuan kedua belah pihak". Dengan demikian salah satu pihak baik suami atau istri tidak dapat mengesampingkan ataupun meninggalkan pihak lainnya untuk melakukan perbuatan hukum yang berhubungan dengan harta tersebut, karena kedudukan mereka seimbang yaitu sebagai pemilik harta bersama.

Akibat kedudukan suami istri yang seimbang, wewenang atas harta bersama pun seimbang, untuk itu dalam hal melakukan perbuatan hukum sesuai Pasal 31 ayat (2) UU No. 1 Tahun 1974 yaitu :"masing-masing pihak berhak untuk melakukan perbuatan hukum". Untuk itu berdasarkan kasus putusan tersebut yang berhak untuk menandatangani persetujuan adalah Lina bukan Jumiyati yang merupakan istri baru 
Amin. Berdasarkan riwayat tanah, perolehan objek terperkara adalah pada saat Amin dan Lina menikah. Hal ini memberikan perlindungan hukum kepada Lina diperkuat dengan peraturan perundang-undangan mengenai harta bersama yang memberikan perlindungan hukum kepada Lina atas haknya dalam harta bersama yang belum di bagi.

\section{Kesimpulan}

Tanggung jawab PPAT terhadap AJBT yang batal demi hukum oleh putusan pengadilan adalah tanggung jawab PPAT secara perdata dilihat dari kebenaran syarat formil dalam akta, namun apabila dari para pihak juga dapat menunjukkan bukti yang kuat di muka pengadilan, maka kebenaran materil juga dilakukan yaitu konstruksi yuridis yang digunakan dalam tanggung jawab PPAT adalah konstruksi perbuatan melawan hukum. PPAT yang membuat akta tersebut akibat kelalaiannya dapat diberhentikan oleh Menteri apabila terbukti bersalah melakukan perbuatan melawan hukum yaitu: diberhentikan dengan hormat, diberhentikan dengan tidak hormat, dan diberhentikan sementara. Perlindungan hukum bagi pemilik tanah dalam akta jual beli tanah PPAT yang batal demi hukum oleh putusan pengadilan adalah dengan membuktikan kepemilikan sertifikat berdasarkan analisis riwayat tanah yang sebenarnya dengan bukti yang nyata, dan adanya penyelidikan terhadap riwayat tanah sebelum sertifikat diterbitkan. Karena pendaftaran tanah di Indonesia menganut sistem publikasi negatif atau stelsel negatif, artinya pendaftaran tanah seseorang di dalam register bukanlah berarti absolut menjadi pemilik tanah tersebut apabila ketidakabsahannya dapat dibuktikan oleh pihak lain.

\section{Daftar Pustaka}

Buku

Alwi, H. (1998).Kamus Besar Bahasa Indonesia, Jakarta: Balai Pustaka.

Azhari. (2018). Hukum Bisnis dalam Era Globalisasi. Banda Aceh: Percetakan Bandar.

Badrulzaman, M. A. (2001). Kompilasi Hukum Perikatan. Jakarta: PT Citra Aditya Bakti. (2005). Aneka Hukum Bisnis. Bandung: Alumni.

Erawati, E \& Budiono, H. (2010). Penjelasan Hukum tentang Kebatalan Perjanjian. Jakarta: Nasional Legal Reform Program.

Fuady, M. (2001). Hukum Kontrak (Dari Sudut Pandang Hukum Bisnis). Bandung: Citra Aditya Bakti.

Hadjon, P. M. (1987).Perlindungan Rakyat Bagi Rakyat di Indonesia (sebuah Studi tentang Prinsip-Prinsipnya, Penanganannya oleh Pengadilan dalam Lingkungan Peradilan Umum dan Pembentukan Peradilan Administrasi Negara), Surabaya: PT. Bina Ilmu. Harjono, (2008). Konstitusi Sebagai Rumah Bangsa, Jakarta: Konstitusi Press.

Krisnawati, I. G. A. A. A. (2015). Pembuktian Per.kara Perdata. Diklat Kuliah.

Marzuki, P. M. (2011). Penelitian Hukum, Jakarta: Rajawali Pers.

Lubis, M. Y. \& Lubis, R. (2008). Hukum Pendaftaran Tanah. Bandung: CV. Mandar Maju. Prodjodikoro \& Wirjono, R. (2004). Asas-Azas Hukum Perjanjian. Bandung: Mandar Maju.

Rahardjo, S. (1983). Permasalahan Hukum di Indonesia. Bandung: Alumni. (2003). Sisi-sisi Lain dari Hukum di Indonesia, Jakarta: Kompas.

Ridwan H.R. (2003). Hukum Administrasi Negara, Yogyakarta: UII Press. 
Salim HS dan Nurbani, E. S. (2017). Penerapan Teori Hukum pada Penelitian Tesis dan Disertasi, Jakarta: PT. Raja Grafindo Persada.

\section{Jurnal}

Bur, A. \& Apriani, D. (2017). Sertifikat Sebagai Alat Pembuktian Yang Kuat Dalam Hubungannya Dengan Sistem Publikasi Pendaftaran Tanah. Jurnal UIR Law Review, 1(2), 127-136. https://doi.org/10.25299/uirlrev.2017.1.02.952

Faridah, U. \& Suryandono, W. (2019). Perlindungan Hukum Terhadap Penjual Atas Jual Beli Tanah Yang Cacat Hukum Dan Notaris/PPAT Yang Telah Meninggal Dunia. Jurnal Notary Indonesian, 1(2), 1-22.

Hadisiswati, I. (2014). Kepastian Hukum dan Perlindungan Hukum Hak Atas Tanah", Ahkam. 2(1), 118-147. https:// doi.org/10.21274/ahkam.2014.2.1.118-146

Paidawati, N. W. P. \& Suharta, I. N. (2016). Sifat Pembuktian Sertifikat Sebagai Tanda Bukti Hak Berdasakan Ketentuan Peraturan Pemerintah Nomor 24 Tahun 1997 tentang Pendaftaran Tanah. Jurnal Kertha Semaya, 4(3), 1-5.

Prawira, I. G. B. Y. (2016). Tanggung Jawab PPAT Terhadap Akta Jual Beli Tanah. Jurnal IUS, 4(1), 64-78.

Rizqi, A. A. \& Yusriyadi. (2018). Perlindungan Hukum Pemilik Sertifikat Hak Atas Tanah Dalam Hal Terjadi Kesalahan Data Penerbitannya. Notarius, 11(3), 141153. https:// doi.org/10.14710/nts.v11i2.23459

Sakti, S. T. I. (2020). Perlindungan Hukum Bagi Para Pihak dalam Perjanjian Jual Beli Tanah Letter C di Bawah Tangan. Jurnal Privat Law, 8(1), 144-150.

Deasy, S. (2014). Proses Pembuktian Dan Penggunaan Alat-Alat Bukti Pada Perkara Perdata Di Pengadilan. Jurnal Hukum Unsrat, 2(1), 124-136.

Veronika, N. (2019). Bentuk Perlindungan Hukum Terhadap PPAT Pasca Perubahan Pasal 66 UU No. 2 Tahun 2014 tentang Jabatan Notaris. Jurnal Indonesian Notary, $1(4), 1-20$.

Wardana, R. A. \& Handayani, I. G. A. K. R. (2016). Pembatalan Akta Jual Beli Yang Cacat Hukum Dengan Putusan Pengadilan. Jurnal Repertorium, 1-15.

Wibawa, K. D. C. S. (2009). Menakar Kewenangan dan Tanggung Jawab Pejabat Pembuat Akta Tanah (PPAT) dalam Prespektif Bestuurs Bevoegheid. Jurnal Crepido, 1(1), 40-51.

Widjaja, H. \& Tanawijaya, H. (2018). Analisis Perbuatan Melawan Hukum Dalam Akta Perjanjian Pengikatan Jual Beli (PPJB) Tanah Antara Koko Purnomo Santoso Dengan Pt. Intan Plaza Adika. Jurnal Hukum Adigama, 1(1). http://dx.doi.org/10.24912/adigama.v1i1.2157

Yusriyadi, AAR. (2018). Perlindungan Hukum Pemilik Sertifikat Hak Atas Tanah Dalam Hal Terjadi Kesalahan Data Penerbitannya. Notarius, 11(3). http://dx.doi.org/10.14710/nts.v11i2.23459 